\title{
Conflict externalization and the quest for peace: Theory and case evidence from Colombia*
}

\author{
Hector Galindo-Silva ${ }^{\dagger}$ \\ Pontificia Universidad Javeriana \\ First Draft: June 2014 \\ This Draft: August 2020
}

\begin{abstract}
I study the relationship between the likelihood of a violent domestic conflict and the risk that such a conflict "externalizes" (i.e. spreads to another country by creating an international dispute). I consider a situation in which a domestic conflict between a government and a rebel group has the potential to externalize. I show that the risk of externalization increases the likelihood of a peaceful outcome, but only if the government is sufficiently powerful relative to the rebels, the risk of externalization is sufficiently high, and the foreign actor who can intervene in the domestic conflict is sufficiently uninterested in material costs and benefits. I show how this model helps to understand the recent and successful peace process between the Colombian government and the country's most powerful rebel group, the Revolutionary Armed Forces of Colombia (FARC).
\end{abstract}

Journal of Economic Literature Classification Numbers: H72, D72

Keywords: Conflict, externalization, peace talks

${ }^{*}$ I am grateful to Raphael Godefroy, David Karp, Alessandro Riboni and two anonymous referees for helpful comments and suggestions. All errors or omissions are mine.

${ }^{\dagger}$ Department of Economics, Pontificia Universidad Javeriana, E-mail: galindoh@javeriana.edu.co 


\section{Introduction}

The existing theoretical literature on civil wars often assumes that a group's decision of whether to fight depends exclusively on the domestic context, i.e. on other domestic groups' decisions. ${ }^{1}$ However, an increasing empirical literature on conflict is demonstrating that the regional context also plays an important role in domestic conflicts. ${ }^{2}$ Researchers are well aware of the regional dimensions of conflicts in Myanmar, Nicaragua, Kosovo, Sudan, Lebanon and Iraq, for example. ${ }^{3}$

In this paper, I develop a simple model of conflict externalization, and provide new casestudy evidence from Colombia. The objective of the model is to formalize an existing theory, and to propose a new mechanism through which the possibility that an external party intervenes in an internal conflict could affect the outcome of the conflict. In addition to demonstrating the applicability of the model, the Colombian case provides new evidence on this topic.

In the model, a government and a group of rebels simultaneously choose whether to attack each other. Attacking is costly, but can also decrease the opponent's military resources, which increases the aggressor's probability of victory. Crucially, the use of violence might cause a third (foreign) actor to join in the conflict. When this happens, I say that the domestic conflict "externalizes."

This externalization changes the power dynamic between the two domestic actors. I assume that only the government's use of violence can trigger such an externalization. For example, consider a group of rebels strategically located along a porous border, where the neighboring country shares an ideology or ethnicity with the rebels. Given the relationship between the rebels and the neighboring country's government, an aggression might be viewed as a violation of the neighboring country's sovereignty and could motivate a military response, starting a conflict spiral that might lead to an international war. ${ }^{4}$ I focus on how the threat of such an external conflict affects the likelihood of peace between domestic actors.

This paper's first main contribution is to show that the risk of externalization increases the likelihood of peace, but that this only happens if a government is sufficiently powerful relative to rebels, if the risk of externalization is sufficiently high, and if a foreign actor is sufficiently uninterested in material costs and benefits.

This paper's second main contribution is new case-study evidence from Colombia. Colombia has suffered one of the world's longest-running internal conflicts. Although many armed groups have participated in the conflict, the left-wing Revolutionary Armed Forces of Colombia (FARC) was always the largest non-government actor. In September 2012, the Colombian

\footnotetext{
${ }^{1}$ See Blattman and Miguel (2010) and Jackson and Morelli (2011) for reviews of this literature.

${ }^{2}$ See Mason et al. (1999), Hegre and Sambanis (2006), Gleditsch (2007), Balch-Lindsay et al. (2008) and Cunningham et al. $(2009,2011)$ for evidence showing that the regional context (e.g. a conflict in a neighboring country, a highly autocratic region, trans-boundary ethnic groups, or direct intervention of external parties) matters for the onset, incidence and duration of civil wars.

${ }^{3}$ See South (2008) for the conflict in Myanmar; Gleditsch and Beardsley (2004) for the Nicaragua-Contras conflict; Crawford (2001) and Kuperman (2008) for Kosovo; Ali et al. (2005) for Sudan; Bouckaert and Houry (2007) for Lebanon; and Gunter (2008) and Morelli and Pischedda (2013) for the Iraqi-Kurdish conflict.

${ }^{4}$ As I will argue later, this situation matches the recent dynamic of the Colombian internal conflict. It is also consistent with Myanmar-Thailand border clashes prompted by Myanmar pursuit of Karen National Liberation Army rebels across the border into Thailand; see South $(2008,2012)$.
} 
government announced the start of new peace negotiations following an extensive military campaign that severely damaged the FARC. This announcement surprised many analysts and national leaders, who expected a few more years of war, ending with a government victory. In July 2016, the Colombian government and the FARC signed a historic peace deal, which earned then-Colombian President Juan Manuel Santos the 2016 Nobel Peace Prize.

Despite its relevance, to the best of my knowledge no rationalist explanation has been proposed to account for both the onset and success of this Colombia's historic peace process with the FARC. I show that the risk of externalization of the Colombian conflict (to Venezuela) was at the root of the peace negotiations, creating what has been called a situation that was "ripe for resolution" Zartman (2000).

The theory proposed in this paper relates to the literature studying the interdependence of intra- and inter-group conflicts (see for instance Baik and Lee, 2000; Stein and Rapoport, 2004; Hausken, 2005; Münster, 2007; Münster and Staal, 2011; Choi et al., 2016). Using models of group contest, these studies examine conflicts within or between groups that occur either sequentially or simultaneously. This paper uses a contest model with sequential actions (as in Baik and Lee, 2000; Stein and Rapoport, 2004; Münster and Staal, 2011), with heterogeneity within groups (as in Choi et al., 2016). However, those studies focus on scenarios in which all members of a domestic group have a common interest in fighting a foreign enemy, whereas this paper focuses on a scenario with two domestic groups, where one group is closely aligned with a foreign group and the other is not.

This paper is also related to the few but increasing theoretical studies on third-party interventions (see Fearon, 1998; Carment and Rowlands, 1998; Werner, 2000; Crawford, 2003; Carment and Rowlands, 2006; Amegashie and Kutsoati, 2007; Münster, 2007; Münster and Staal, 2011; Kydd and Straus, 2013). Specifically, it is consistent with what this literature calls the "deterrence" hypothesis: the idea that an external party can play a crucial role in the outcome of an internal conflict by deterring one of the domestic parties from making a decision that harms its opponent (see Fearon, 1998; Carment and Rowlands, 1998; Werner, 2000; Crawford, 2003). In my model, peace is possible because the risk of externalization deters the government from attacking the rebels, given that it could prompt externalization that could strengthen the rebels. ${ }^{5}$ As in Kydd and Straus (2013), I find that whether the potential for an external intervention makes war less likely depends on whether power is balanced, but unlike them, I find that peace is more likely when the government is stronger, even if an intervention strengthens the rebel group. ${ }^{6}$

The outline of the paper is as follows. Section 2 presents the model. Section 3 presents and analyzes the case study based on the model. Section 4 concludes.

\footnotetext{
${ }^{5}$ Although the argument does not account for "moral hazard" - that an external intervention biased in favor of one party might make this party more belligerent - the model in this paper can be easily extended to include this possibility, which does not change the key findings. However, this phenomenon does not seem to play an important role in the Colombian conflict, and despite its simplicity, the model is able to provide non-trivial and new and empirical predictions.

${ }^{6}$ This paper also shares similarities with Bakshi and Dasgupta (2019), who study how the balance of power between groups within a country affects group conflict in another country. Like Bakshi and Dasgupta, this paper also studies the relationship between cross-border spillovers and conflict. However, unlike Bakshi and Dasgupta (2019), the results in this paper crucially depend on the possibility of interstate conflict.
} 


\section{Model}

In this section, I develop a simple model that illustrates how the risk of a domestic conflict externalizing can affect the outcome of the conflict.

Suppose that a government faces a rebel group. The government's main goal is to defeat the rebels. The rebels are not strong enough to defeat the government, but can harm the government and thereby avoid being defeated. Both parties simultaneously choose whether to attack the other or pursue peace. If either party attacks, the other party suffers a loss $L$ in military resources, and both parties lose an amount of wealth, $C{ }^{7}$ Importantly, if the government attacks the rebels, then a foreign government $F$ can intervene. This intervention is assumed to favor the rebel group, ${ }^{8}$ and always implies that the government is unable to defeat the rebel group. ${ }^{9}$

The model focuses on the role of the government's initial resources in determining the outcome of the game. I use $G$ to denote these resources. I assume that $G \in(L, \bar{G}) .{ }^{10}$ The probability of the government and the rebels winning, for all outcomes in which $F$ does not intervene, depends on $G$. To model these probabilities, I first define a function $Z$ such that $Z(x)=0$ for all $x \leq 0$, so that $Z^{\prime}=0$ for all $x<0 ; Z^{\prime}>0$ and $Z^{\prime \prime} \leq 0$ for all $x \in(0, \bar{G})$; and $Z(x)=1$ for all $x \geq \bar{G}$. This function will be key in the analysis, and can interpreted as the government's probability of defeating the rebels if the group with the most resources wins, ${ }^{11}$ and if the resources of the rebels are random. ${ }^{12}$

\footnotetext{
${ }^{7}$ The assumption that $C$ and $L$ are the same for both groups seem restrictive. However, the results are robust to potential differences, within certain constraints.

${ }^{8}$ The assumption that an external intervention can occur only if the government attacks the rebels is crucial for the main result (that, under certain conditions, peace is selected as the unique equilibrium). If an external intervention could also occur when the rebels attack the government, then conflict would always be an equilibrium, and the conditions for an additional peaceful equilibrium would be harder to achieve. Thus, this alternative scenario would imply weaker results. However, the mechanism would be the same. The details for this alternative scenario are available upon request.

${ }^{9}$ For an intuition of the types of situations I try to model, consider a domestic conflict where some rebels are located close to a border shared with $F$. Given the proximity of the rebels to $F$, and the ability of the rebels to move between the two countries (because of either porous borders or sympathy from $F$ ), an offensive action by the government in the rebels's controlled territory might harm the citizens of $F$ or be interpreted by $F$ as a violation of its sovereignty. This implies a strong reaction by $F$ to try and ensure that the government is unable to defeat the rebels. This intervention can be interpreted either as a direct attack on the government, or as military aid to the rebels. In Section 3, I argue that this scenario is consistent with what occurred prior to the peace process between the Colombian government and the FARC.

${ }^{10}$ The fact that $G>L$ implies that the harm caused by the government's violence is limited by the government's resources. The condition $\bar{G}>G$ defines an upper bound for $G$.

${ }^{11}$ This means that if the resources of the groups $A$ and $B$ are $R_{A}$ and $R_{B}$, respectively, then the probability of victory for group $A$ is 1 if $R_{A}>R_{B}, 0$ if $R_{A}<R_{B}$ and $1 / 2$ if $R_{A}=R_{B}$. This form of modeling the winning probabilities is known as an "all-pay auction." It has been used to study contests in which group members exert effort that translate into "group effort" (see for instance Baik et al., 2001; Barbieri et al., 2014; Chowdhury et al., 2016; Chowdhury and Topolyan, 2016a,b). Under this interpretation, the scenarios in which one group defends against another group's attack (as in Chowdhury and Topolyan, 2016a), and where the aggregation technology is asymmetric among the contesting groups (as in Chowdhury and Topolyan, 2016b) are particularly important.

${ }^{12}$ To see this, define $R$ as the resources of the rebels, and assume that $R$ is a random variable on $\mathbb{R}$ with a cumulative distribution function $Z$ such that $Z(x)=0$ for all $x \leq 0, Z^{\prime}>0, Z^{\prime \prime} \leq 0$ for all $x \in(0, \bar{G})$, and $Z(x)=1$ for all $x \geq \bar{G}$. Thus, if the winning probabilities are defined as an "all-pay auction," we have
} 
Specifically, let $Z(G)$ be the government's probability of defeating the rebels when both parties attack and $F$ does not intervene. When the rebels attack but the government chooses peace, the government loses $L$ in military resources, so its probability of winning is $Z(G-L)$. The winning probabilities are defined analogously when the government attacks but neither the rebels nor the foreign country attack. ${ }^{13}$ When no group attacks, peace occurs; in this scenario, the parties compete in an election in which each party's probability of winning depends on the relative initial resources. ${ }^{14}$

Finally, $F$ 's decision of whether to intervene depends negatively on the resources of the government: the greater these resources, the less likely it is that $F$ will intervene because $F$ 's potential losses are greater. However, and importantly, $F$ may not be purely interested in material costs and benefits. F may have ideological or religious motivations, which, insofar as they involve agents that can be difficult to negotiate with, can be viewed as being not materially based (in this respect, see Jackson and Morelli, 2011). ${ }^{15}$ Specifically, F's goals are purely material with probability $1-\phi$, in which case its decision to intervene depends on $G$. F's goals are not materially based with probability $\phi$, in which case the probability of an intervention is assumed to be exogenous and normalized to one. ${ }^{16}$

\section{Timing}

(1) The government and the rebels simultaneously decide whether to attack each other.

(2) If either party decides to attack, a violent conflict occurs. If neither party attacks, peace occurs, and the parties compete in an election in which each party's probability of winning depends on its relative initial resources.

(3) If there is a violent conflict, both parties face exogenous costs $C>0$. In addition, the military resources of a party decrease by $L$ if it is attacked.

(4) $F$ observes whether the government attacked. If the government attacked, $F$ intervenes with probability $\phi$, and makes a determination on whether or not to intervene based on G with probability $(1-\phi)$. If $F$ intervenes, the government cannot defeat the rebels.

(5) The violent conflict ends. Each group receives a payoff according to the outcome, which is described in the next subsection.

that the government's probability of victory is $\operatorname{Pr}[G>R]=Z(G)$ if both groups attack. The other winning probabilities can be defined analogously. The randomness of $R$ is consistent with the rebels being somewhat informal. This may be particularly true if the rebels are located along the borders with $F$, if these borders are porous, and if there is uncertainty about how effectively $F$ surveils its border (as the level of arms or troops flowing in from $F$ may be unknown).

${ }^{13}$ As previously mentioned, when $F$ intervenes, the government's probability of defeating the rebels is 0 .

${ }^{14}$ This can be interpreted as an scenario in which the political parties that represent the interests of the groups compete for seats in the national assembly under a proportional representation system. It is also consistent with a number of seats in the national assembly being given to the rebels under the terms of a peace deal that guarantees proportional representation for the rebels. These scenarios are consistent with what occurred after the 2016 peace accord between the Colombian government and the FARC.

${ }^{15}$ As will be discussed in Section 3, ideology is crucial to understanding Venezuela's motivation to intervene in the Colombian conflict. In addition to Jackson and Morelli (2011), see Maynard (2019), who discusses the role of ideology in armed conflicts, and Owen (2010), who provides examples in international politics.

${ }^{16}$ This normalization is without loss of generality; what matters is that the probability of an intervention when $F$ 's goals are not materially based is exogenous. 


\section{Payoffs}

The preferences of the domestic groups are characterized by a Bernoulli utility function, where each party gets a payoff of 1 if it wins, and 0 if it loses. The payoff function of the government is denoted by $\pi$, and the payoff function of the rebels is denoted by $\rho$. Note that these functions depend on what the domestic groups simultaneously decide (either attack $(a)$ or peace $(p))$, as well as on the foreign government's decision about whether to intervene $(a)$ or $\operatorname{not}(p)$.

Since the government and rebels do not know whether $F$ will intervene when deciding on their military actions, I use $\Phi$ to denote each group's expectation that such an intervention will occur (conditional on an attack by the government). Thus, given an attack by the rebels, the government's expected payoff from attacking is $\pi(a, a)=(1-\Phi) Z(G)-C .{ }^{17}$ The expected payoffs for all cases, after rearranging and omitting some constants, are given in Table I.

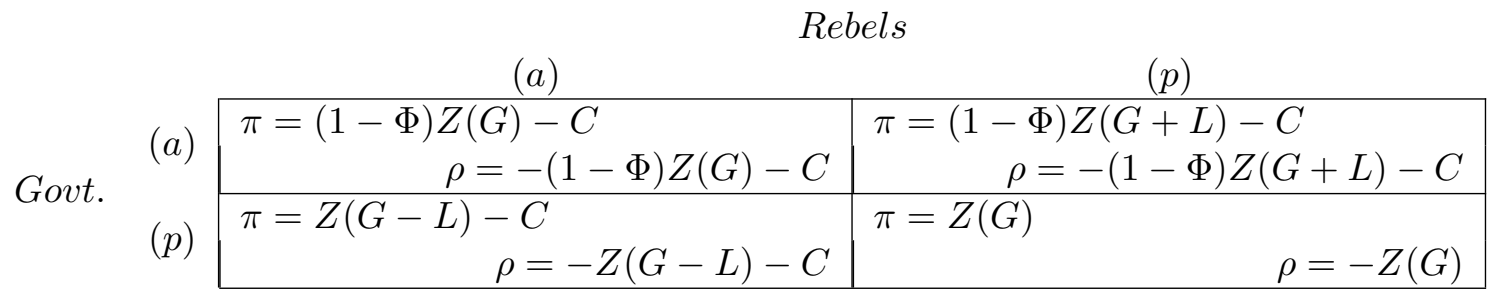

Table I: Expected payoffs for government and rebels

I model F's decision about whether to intervene in a very simple and stylized way. First, I assume that a foreign intervention is less likely when the government is stronger. Then, I define $W(G)$ as the probability of an intervention from the perspective of the government and rebels when $F$ is interested in material benefits, and where $W$ is a function such that $W(x)=0$ for all $x \geq A>\bar{G}, W(x)=1$ for all $x \leq 0$, and for all $x \in(0, A), W^{\prime}<0$ and $W^{\prime \prime} \leq 0 .^{18}$

\section{Additional assumptions}

Assumption 1. $C>Z(L)$.

Assumption 1 guarantees that the cost of using violence is high enough that a peace agreement is always possible.

Assumption 2. Let $\sup \left\{\frac{Z^{\prime}(G)}{W^{\prime}(G)} \mid G \in(L, \bar{G})\right\} \equiv k$. Then $W(\bar{G}) k<-1$.

\footnotetext{
${ }^{17}$ Note that, with some abuse of notation, I have defined $\pi(a, a) \equiv E_{x}[\pi(a, a, x)]$, where $x \in\{a, p\}$ is $F^{\prime}$ 's choice, and $E_{x}$ is the government's expectation about $x$.

${ }^{18} \mathrm{~A}$ very simple micro-foundation for $W$ is the following. First, define $F$ 's payoff as equal to $B-G$ if $F$ intervenes, and 0 if it does not intervene, where $B$ represents any material benefit derived from the intervention. Then, assume that $B$ is unknown to the government and the rebels and that, from the point of view of these parties, it has a cumulative distribution function $V$ defined on $\mathbb{R}$ such that $V(x)=1$ for all $x \geq A>\bar{G}$, $V(x)=0$ for all $x \leq 0$, and for all $x \in(0, A), V^{\prime}>0$ and $V^{\prime \prime} \geq 0$. Finally, set $W(x) \equiv 1-V(x)$.
} 
Assumption 2 is a technical condition, and allows for a simpler characterization of the government's best response to a rebel attack. ${ }^{19}$

Assumption 3. $(1-W(\bar{G}))>Z(\bar{G}-L)$.

Assumption 3 guarantees that given an attack by the rebels, the government's best response function dictates that the government should also attack, even if the probability of a foreign intervention is small.

\subsection{Equilibrium}

I will now characterize the equilibrium of the game. I focus on the intuition for the main equilibrium decisions, and leave the formal derivation to the Appendix.

First, note that from the point of view of both the government and rebels, a foreign intervention will occur with probability $\Phi=\phi+(1-\phi) W(G)$ (conditional on the government attacking). Replacing this expression in the payoff functions of the government and the rebels, and computing each group's best response function, it is possible to establish a set of nontrivial conditions under which a conflict occurs in equilibrium. These conditions focus on the exogenous component of the risk of a foreign intervention (i.e. $\phi$ ), and on the government's resources (i.e. $G$ ). They constitute the main result of this section, which is summarized in the following proposition:

Proposition 1. Consider the above-described game. Let $\bar{\phi} \equiv 1-\frac{Z(\bar{G}-L)}{(1-W(\bar{G}))}$. Given Assumptions 1-3, the following hold:

(i) Given any $\phi \in[0,1]$ and any $G \in(L, \bar{G}),(p, p)$ must constitute a Nash equilibrium.

(ii) Whenever $\phi \leq \bar{\phi},(a, a)$ constitutes a Nash equilibrium for all $G \in(L, \bar{G})$.

(iii) Whenever $1>\phi>\bar{\phi}$, there exists $\hat{G}(\phi) \in(L, \bar{G})$, with $\hat{G}^{\prime}(\phi)<0$, such that $(a, a)$ constitutes a Nash equilibrium if and only if $G \leq \hat{G}(\phi)$.

(iv) Whenever $\phi=1,(p, p)$ constitutes the unique Nash equilibrium.

(v) Neither $(a, p)$ nor $(p, a)$ can constitute a Nash equilibrium.

Proof. See Appendix.

To understand the intuition behind Proposition 1, first note that if the risk of an external intervention is low, a well-resourced government can easily defeat the rebels. Such a government will have a strong incentive to attack the rebels, so a violent conflict will constitute a Nash equilibrium. In addition, note that this scenario is consistent with the assumption that the risk of an external intervention decreases with the strength of the government.

However, and importantly, recall that the risk of an external intervention only partially depends on the government's resources. How does this affect the mechanism described in the

\footnotetext{
${ }^{19}$ This assumption can be relaxed at the cost of much less general functions $Z$ and $W$. Two functions $Z$ and $W$ that satisfy Assumption 2 are: $Z(x)=x / \bar{G}$ if $x \in[0, \bar{G}], Z(x)=0$ if $x<0, Z(x)=1$ if $x>\bar{G}$, and $W(x)=(1-x / A)$ for $x \in[0, A]$ and with $A>2 \bar{G}$. More generally, when $Z(x)=(x / \bar{G})^{\beta}$ with $\beta \in(0,1]$, and $W(x)=(1-x / A)^{\gamma}$ with $\gamma \in(0,1]$, then it is easy to see that Assumption 2 holds if $\left(\frac{\beta}{\gamma}\right)\left(\frac{A-\bar{G}}{\bar{G}}\right)>1$. I thank a referee for suggesting this Assumption and example.
} 
last paragraph? Crucially, it allows for a non-trivial and new mechanism through which peace can prevail (i.e. in which $(p, p)$ is selected as the unique Nash equilibrium).

This mechanism is based on the idea that when the risk of an external intervention does not entirely depend on the material resources of the groups in conflict, a well-resourced government may have less incentive to attack the rebels. Why? Because this government is better able to tolerate a rebel attack, and by doing so, it can decrease the risk of an external intervention. Importantly, this may happen even if a well-resourced government faces a relatively low probability of an external intervention. For a well-resourced government, the pro-peace effects of resources (a greater capacity to tolerate a rebel attack) can outweigh pro-war effects (a greater capacity to defeat the rebels).

Proposition 1.(iii) establishes two conditions for the selection of the peaceful scenario described in the last paragraph: the foreign actor should be sufficiently uninterested in material costs and benefits (such that the strength of the government is not a big deterrent to intervening), and the government should be sufficiently resourced (such that it can tolerate an attack from the rebels without being seriously harmed). ${ }^{20}$ To the best of my knowledge, this result is new in the literature. In the next section, I show that it is crucial to understanding the intriguing peace deal between the Colombian government and the FARC.

\section{Case study evidence from Colombia}

In this section, I show how the model proposed in the previous section explains case study evidence from Colombia. I use information from the main actors in the Colombian conflict, as well as from the secondary academic literature.

\subsection{Background}

The conflict between the Colombian government and the left-wing rebels dates back to the late 1950s. Its origins have been associated with the founding of the FARC, which was always

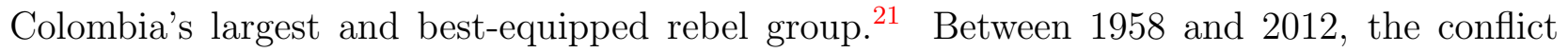
claimed at least 220,000 lives (see GMH, 2013, p. 31).

From the 1980s until its end, the Colombian conflict was accompanied by several negotiations, including three failed peace talks with the FARC (see Sanchez, 2001; Chernick, 2009; Nasi, 2009). This section focuses on the most recent (and successful) peace talks, which occurred from 2010 to 2016. These peace talks were preceded by the "Caguán" peace process, which occurred from 1998 to 2002, and which failed miserably. A relatively weak government, amateurish bargaining teams and spoilers (actors who use violence to undermine peace talks) are some of the explanations given for Caguán's failure (see Kline, 2007; Nasi, 2009). The breakdown of the Caguán peace process led to the election, in 2002, of a hawkish and far-right

\footnotetext{
${ }^{20}$ If either of these two conditions are not satisfied, Proposition 1.(ii) and Proposition 1.(iii) imply that, in equilibrium, both the government and the rebels will attack (which means that $(a, a)$ also constitutes a Nash equilibrium). A weak government will attack the rebels (regardless of the risk of foreign intervention) when the government has a limited ability to defend itself from a rebel attack if the government chooses peace.

${ }^{21}$ Other smaller rebel groups participated in Colombia's conflict. These include other left-wing insurgents and right-wing paramilitaries. The most important left-wing insurgent other than the FARC is the National Liberation Army (ELN). The main right-wing paramilitary group was the United Self-Defense Forces of Colombia (AUC), which officially demobilized in 2006.
} 
president, Alvaro Uribe, and started a period of intense war between the government and the FARC.

\subsubsection{Government empowerment}

During the 2000s and early 2010s, Colombia's government pursued an all-out military effort against the FARC. Due to an increase in defense spending and a significant improvement in military effectiveness, the Colombian government achieved relative success: during this period, the FARC suffered the worst blows in its history. According to the Colombian Ministry of Defense, an average of 40 FARC members were captured or killed annually from 2002 and 2011. In the same period, roughly 17 members deserted the FARC each year, and the number of FARC combatants was halved. ${ }^{22}$ The government also killed the head of the FARC and several other leaders, in an action characterized by the Colombian president as "the most devastating blow that this group has suffered in its history." ${ }^{23}$ These actions were deeply resented by the FARC. ${ }^{24}$

During this period, the FARC retreated from key regions in the center of the country (i.e. the departments of Cundinamarca, Tolima, and Santander) to border areas with Venezuela and Ecuador (i.e. to the departments of Nariño, Cauca, Caquetá, Norte de Santander and Arauca) (see IISS, 2011; Avila, 2013). The FARC's decision to move to the periphery of the country was strategic, given ideological similarities between the FARC and the governments of Venezuela and Ecuador, and the porousness of the borders with these two countries (see Owen, 2010, p. 257). The FARC's decision, combined with a hawkish military strategy by the Colombian government, brought the three countries to the brink of war. I argue that it also raised the likelihood of a peaceful solution.

\subsubsection{On the brink of war}

In March 2008, Colombian security forces crossed into Ecuador to assault an outpost of the FARC. More than two dozen rebels were killed, including a high-ranking leader thought by many to be FARC's second-in-command. The Colombian government also captured computers with documents indicating that Venezuela had been supporting the FARC (see IISS, 2011).

The assault caused a serious diplomatic incident between Colombia and Ecuador. Ecuador immediately broke off diplomatic relations with Colombia. Venezuela, in solidarity with Ecuador, expelled Colombia's ambassador and other diplomats. ${ }^{25}$ Venezuela and Ecuador also sent troops to the Colombian border, advising that any additional violations of their sovereignty would result in war. ${ }^{26}$ The tension reached a peak in July 2010 when, weeks before a change in Colombia's government, the Colombian press secretary provided evidence of a FARC presence in Venezuela to international authorities. ${ }^{27}$

\footnotetext{
${ }^{22}$ See Ministerio de Defensa (2009) and https://www.youtube.com/watch?v=vnuqZOwOBoo. The exact number of FARC members who deserted or were captured or killed has been debated by analysts (Avila, 2013; Rico, 2013) and the FARC (FARC-EP, 2013b, Feb. 12), but analysts agree with the government that the number of combatants fell by roughly half during the 2000s.

${ }^{23}$ Translation by the author from https://www . youtube. com/watch?v=UIOCJzJLsxU.

${ }^{24}$ See http: //www.rebelion.org/noticia.php?id=138858.

${ }^{25}$ See The New York Times (2008, Mar. 4)

${ }^{26}$ See https : / /www . youtube.com/watch?v=Xp7Gs1-tm1w.

${ }^{27}$ According to the Colombian press secretary, "For six years the Colombian government sustained a patient
} 
In the following days, the Colombian Ambassador to the Organization of American States (OAS) presented photographs, maps, coordinates, and videos proving the presence of illegal armed groups in Venezuelan territory. ${ }^{28}$ Venezuela reacted by breaking off diplomatic relations with Colombia, sending more troops to the border and ordering them to be on full alert. Venezuela's then-President Hugo Chavez said:

To maintain our dignity, we do not have any other option but to sever diplomatic ties with Colombia [...] We will be on alert - I have ordered the maximum alert along our border [...] Uribe is a threat for peace. He is even able to establish a fake camp in our territory and raid it to start a war. ${ }^{29}$

The Colombian government was aware of the high risk of war, particularly if it violated a neighbor's sovereignty. The Colombian Minister of Defense at the time, Gabriel Silva, said:

I said privately to President Uribe, "If you give an authorization, I will bring back to Colombia [all FARC leaders] who are there [in Venezuela]" [...] He did not authorize. He said it was too risky for the country and for national security [...] I do believe that there was very nearly a war with Venezuela. (Davila, 2014, p. 89-91; translation of the author).

\subsubsection{A moment in history}

In July 2010, Colombia severed diplomatic relations with Venezuela. Two weeks later, a new Colombian president, Juan Manuel Santos, took office. Known for his strategic pragmatism, Santos was closely associated with Uribe's successful military campaigns against the FARC and elected with a mandate to continue Uribe's hard-line policies. ${ }^{30}$

From his early days in office, Santos combined an extremely aggressive campaign against the FARC with efforts to improve diplomatic relations with Venezuela. Ten days after he was sworn in, diplomatic relations with Venezuela were restored, and approximately one month later, Santos announced the death of the FARC's second-in-command and leader of its strongest fighting division. One year later, the FARC's top leader, who went by the nom de guerre of Alfonso Cano, was killed. The FARC's choice for Cano's replacement, whose nom de guerre was Timochenko, was also influential: Timochenko was known for operating along the border with Venezuela and for having lived there previously. ${ }^{31}$ In addition, many people had raised concerns about the close ties between Timochenko and important figures in the Venezuelan government. ${ }^{32}$

In September 2012, almost one year after Timochenko had become the FARC's leader, the Colombian president announced that his government and the FARC had agreed to start a peace process. The announcement surprised analysts and national leaders. ${ }^{33}$ These peace

dialogue with the Venezuelan government, on various occasions providing it information on the location of terrorists in that territory. All was unsuccessful with respect to terrorist leaders. We must once again consider taking the matter to international authorities." See Presidencia (2010, July 16).

${ }^{28}$ See OAS (2010, July 22) and https://wWw. youtube.com/watch?v=J2WOEO27yEQ.

${ }^{29}$ Translation by the author from https : //www. youtube.com/watch?v=ql_AFMvwg9U. As Serbin and Serbin (2017) say, "this mobilization of troops was not a minor factor [...] Since 1987 [...] there had been no mobilization of the Venezuelan military at this scale" (see Serbin and Serbin, 2017, p. 241).

${ }^{30}$ See Revista Semana (2010, June 12).

${ }^{31}$ See El Tiempo (2011b, Nov. 15) and El Tiempo (2011a, Nov. 19).

32 Timochenko was called the FARC's "ambassador" to Venezuela (see Caracol Noticias, 2010, Mar. 2).

${ }^{33}$ See Revista Semana (2012, Sept. 3) for initial reactions. 
talks were the first open negotiations in a decade. In July 2016, Colombian President Juan Manuel Santos and the FARC signed a historic peace deal. ${ }^{34}$ In October 2016, Juan Manuel Santos was awarded the Nobel Peace Prize for his efforts to end the Colombian civil war. ${ }^{35}$

\subsection{Analysis}

Why did Colombia and the FARC decide to pursue peace? I suggest that the risk of externalization of the Colombian conflict to Venezuela, the politicization of Venezuela's foreign policy, and the military strength of the Colombian government are at the root of the peace deal, creating what some literature on conflict has called a "ripe for resolution" situation (e.g. see Zartman, 2000).

The FARC's motivations for peace seem clear: it suffered significant setbacks between 2002 and 2011, and its leaders seemed convinced that they had no chance of defeating their enemy. Talking about the relevance of the setbacks, the FARC's leader, Timochenko, said in 2012: "I can't deny we've received serious blows - and extremely painful ones. The deaths of four members of the National Secretariat can't be minimized [...] it's obvious that today's conditions are not the same as a decade ago." 36 Asked why the FARC decided to negotiate with Santos, Timochenko responded that the costs of continuing the conflict would have been very high: ${ }^{37}$

Whatever may come, persistent conflict will entail many more deaths and great destruction, more sorrow and tears, more poverty and misery for some and greater wealth for others. Imagine the lives that could have been saved over the past 10 years. That's why we seek negotiations, a solution without blood, and an understanding through political routes. (Carlos Lozano's website, 2012, Sept. 19; translation of the author).

The Colombian government's motivations for negotiating with the FARC are less apparent. Analysts and the Colombian government have highlighted the increase in the power of Colombian forces relative to the FARC. ${ }^{38}$ But if the Colombian government was winning the war, why wouldn't it continue fighting the FARC for a few more years, as advocated for by former president Uribe? ${ }^{39}$ War is costly and unpredictable, so rational agents should have incentives to reach peaceful settlements that all would prefer to war. However, from the point of view of the majority of the Colombian population, media, and important leaders, just before the peace talks were made public, the FARC were close to being defeated. Thus, the government's cost of war could be perceived as being very low. In addition, at the time, a peace

\footnotetext{
${ }^{34}$ See The New York Times (2016a, Sept. 26).

${ }^{35}$ See The New York Times (2016b, Oct. 7).

${ }^{36}$ Carlos Lozano's website (2012, Sept. 19), translation of the author.

${ }^{37}$ The FARC's strategy may have always been respond to peace with peace. According to the FARC's leader, the FARC "negotiate because a political solution has always been our objective, and also that of the people's movement" (Carlos Lozano's website, 2012, Sept. 19, translation of the author). This awareness was also recognized by FARC's representative of the peace delegation, Pablo Catatumbo: "We are ready to start preparing the way that will lead us towards the expression of our regret for what has happened ... No doubt there has also been harshness and pain caused from our side." (FARC-EP, 2013a, translation of the author).

${ }^{38}$ For instance, Colombian president Santos said in 2012, "If we can talk about peace now [...] it is because of the effectiveness of our armed forces." (See Presidencia, 2012b, Oct. 25, translation of the author).

${ }^{39}$ See Caracol Noticias (2012, Oct. 28).
} 
process seemed riskier, and the FARC was widely seen as untrustworthy. ${ }^{40}$ I argue that the main reasons the government chose peace was the high risk of an international conflict with Venezuela, the extreme politicization of Venezuela's foreign policy, and the Colombian government's significant military strength. According to the theory proposed in Section 2, these conditions are sufficient for a peaceful equilibrium.

Were these conditions satisfied just before the start of the peace talks between the Colombian government and the FARC? I already argued (in subsections 3.1.1 and 3.1.2) that two of these conditions were likely satisfied. First, I showed that just before the start of the peace talks, the government was as strong as ever. A military victory by the FARC (or any other non-state armed group) was seen as so unlikely that the discussion was entirely focused on when - not if - the government would defeat the guerrilla groups. Second, I showed that just before Santos took power, the risk of an interstate conflict between Colombia and Venezuela was extremely high. This risk was directly related to the presence of the FARC in Venezuelan territory, the very likely possibility that Colombia might violate Venezuelan sovereignty to pursue the rebels, and Venezuela's determination to respond if this happened.

The third condition — the extreme politicization of Venezuela's foreign policy — was also met. According to Serbin and Serbin (2017), Venezuela's oil-based foreign activism was amplified under the presidency of Hugo Chavez, and, importantly, included:

"the unbridled involvement of the president in foreign affairs and its extreme politicization [...] [and this trait was expressed in] the role assigned to the armed forces in dealing with a potential asymmetric conflict with the United States, in developing links and military exchanges with countries in the region and beyond, and in establishing ties with irregular forces such as the guerrilla movements" (Serbin and Serbin, 2017, p. 239)

The conflict with Colombia just before the start of the peace talks seems to be a perfect example of this activism: Colombian had Latin America's most pro-American president, the Colombian armed forces were perceived by Chavez as being commanded by the United States, ${ }^{41}$ and the FARC and Chavez were not only ideologically very close (i.e. both were left-wing ad anti-American), but shared an explicit Pan-American "Bolivarian" discourse. ${ }^{42}$

\section{Conclusion}

In this paper, I develop a simple model of conflict externalization and provide new case study evidence from Colombia. The first main contribution of the paper is to show that the risk of externalization of a domestic conflict increases the likelihood of peace, but that this only happens if the domestic government is sufficiently powerful, if the risk of an external intervention is sufficiently high, and if the foreign party that may intervene is sufficiently uninterested in material costs and benefits.

\footnotetext{
${ }^{40}$ In the speech announcing the opening of peace talks, Santos said, "There comes a moment in history when you have to take risks to arrive at a solution [...] This is one of those moments." (See Presidencia, 2012a, Sept. 4, translation of the author).

${ }^{41}$ Motivated by Colombia's plans to allow the US to use seven of its military bases, Chavez said in 2009: "The Yankees are starting to command the Colombian armed forces. They are the ones who are in charge" (Financial Times, 2009, Agu. 10)

${ }^{42}$ See Revista Semana (2008, Jan. 19).
} 
In the second part of the paper, I use the model to examine the Colombian conflict. I focus on peace talks that occurred between 2010 and 2016 between the Colombian government and the FARC. The second main contribution of the paper is to show how the risk of externalization of the conflict to Venezuela played a crucial role in the success of these talks.

Although the theory is inspired by the Colombian conflict, its application is not limited to this case. The model can be applied to any internal conflict in which governments, undertaking cross-border counterinsurgency actions, initiate military actions against neighboring states. While other explanations exist to explain how Colombian peace talks evolved, such as less ideological extremism and less militarism from both parties, the evidence shows that the possibility of externalization should be considered in any examination of the issue. 


\section{Appendix}

Proof of Proposition 1. I solve the game by backward induction. Having examined F's decision about whether to intervene in the main text, I must now examine the other groups' optimal decisions about whether to attack each other. I start by showing that, under Assumption 1, peace (i.e., $(p, p)$ ) always constitutes a Nash equilibrium of the game. Then, I show that under Assumptions 2 and 3, there is a threshold value for $\phi$ that determines whether war (i.e., $(a, a)$ ) is also a Nash equilibrium of the game. I conclude by showing that neither $(a, p)$ nor $(p, a)$ can constitute a Nash equilibrium.

First, define $\pi(p, p)-\pi(a, p)=Z(G)-(1-\phi)(1-W(G)) Z(G+L)+C$, where $\pi(p, p)$ and $\pi(a, p)$ are from Table I, and where I have used the fact that $\Phi=\phi+(1-\phi) W(G)$. Now note that if $\pi(p, p)>\pi(a, p)$, then when the rebels seek peace, the government's best response is also to seek peace. In the last expression, note that $\pi(p, p)>\pi(a, p)$ if and only if

$$
C>(1-\phi)(1-W(G)) Z(G+L)-Z(G) .
$$

Now note that since $Z(0)=0, Z(x)=1$ for all $x \geq \bar{G}$, and $Z^{\prime}>0$ and $Z^{\prime \prime} \leq 0$ for all $x \in(0, \bar{G})$, then Assumption 1 implies that $C>Z(x+L)-Z(x)$ for $x \geq 0$. In particular, Assumption 1 implies that $C>Z(G+L)-Z(G)$ for $G \in(L, \bar{G})$. Thus, since $(1-\phi)(1-W(G)) \leq 1$ for all $G \in(L, \bar{G})$, we have that $(1)$ holds for all $G \in(L, \bar{G})$.

Now define $\rho(p, p)-\rho(p, a)=-Z(G)+Z(G-L)+C$, where $\rho(p, p)$ and $\rho(p, a)$ are from Table I, and where I have used the fact that $\Phi=\phi+(1-\phi) W(G)$. Note that if $\rho(p, p)>\rho(p, a)$, the rebels' best response is to seek peace, given that the government also seeks peace. In the last expression, note that $\rho(p, p)>\rho(p, a)$ if and only if

$$
C>Z(G)-Z(G-L)
$$

Since $C>Z(x+L)-Z(x)$ for all $x \geq 0$ (which follows from Assumption 1, as previously shown), then choosing $x=G-L$ for $G \in(L, \bar{G})$, we have that (2) holds for all $G \in(L, \bar{G})$.

We therefore have that peace (i.e., $(p, p))$ constitutes a Nash equilibrium of the game. This proves Proposition 1.(i).

Now I establish the conditions under which war (i.e., $(a, a))$ is also a Nash equilibrium of the game. To do this, first define $D \equiv \pi(p, a)-\pi(a, a)$, and note that if $D>0$, then the government's best response to a rebel attack is to choose peace, and if $D<0$, the government's best response is to attack. From Table I, note that $D$ is equal to

$$
D=Z(G-L)-(1-\phi)(1-W(G)) Z(G)
$$

where I have used the fact that $\Phi=\phi+(1-\phi) W(G)$. Differentiating (3) with respect to $G$, we get

$$
\frac{d D}{d G}=Z^{\prime}(G-L)-(1-\phi)(1-W(G)) Z^{\prime}(G)+(1-\phi) W^{\prime}(G) Z(G)
$$

which, rearranging the terms, is equivalent to

$$
\frac{d D}{d G}=\left[Z^{\prime}(G-L)-(1-\phi) Z^{\prime}(G)\right]+(1-\phi) W^{\prime}(G) Z(G)\left[1+\frac{W(G) Z^{\prime}(G)}{W^{\prime}(G) Z(G)}\right] .
$$

In (5), note that $Z^{\prime}(G-L)-(1-\phi) Z^{\prime}(G) \geq 0$ since $Z^{\prime \prime}(x) \leq 0$ for all $x \in(L, \bar{G})$. Thus, given any $\phi \in[0,1]$, a sufficient condition for $\frac{d D}{d G}>0$ is

$$
1+\frac{W(G) Z^{\prime}(G)}{W^{\prime}(G) Z(G)}<0
$$


given that $W^{\prime}<0$ for all $x \in(0, A)$ where $A>\bar{G}$. I will now show that Assumption 2 implies that (6) holds for all $G \in(L, \bar{G})$. To see this, note that

$$
1+\frac{W(G)}{Z(G)} \frac{Z^{\prime}(G)}{W^{\prime}(G)} \leq 1+\frac{W(G)}{Z(G)} k
$$

where $k \equiv \sup \left\{\frac{Z^{\prime}(G)}{W^{\prime}(G)} \mid G \in(L, \bar{G})\right\}$. In addition, note that since $W^{\prime}(x)<0$ and $Z^{\prime}(x)>0$ for all $x \in(0, \bar{G})$, we have that $k \leq 0$, and that

$$
1+\frac{W(G)}{Z(G)} k \leq 1+W(G) k \leq 1+W(\bar{G}) k .
$$

Combining (7) and (8), we have that

$$
1+\frac{W(G)}{Z(G)} \frac{Z^{\prime}(G)}{W^{\prime}(G)} \leq 1+W(\bar{G}) k .
$$

So, if $1+W(\bar{G}) k<0$ (as stated in Assumption 2), then (6) holds. And if (6) holds, we have that (5) is greater than zero given any $\phi \in[0,1]$ and for all $G \in(L, \bar{G})$.

Next, note that $\frac{d D}{d G}>0$ and $L<\bar{G}$ implies that

$$
D \in(-(1-\phi)(1-W(L)) Z(L), Z(\bar{G}-L)-(1-\phi)(1-W(\bar{G})) Z(\bar{G}))
$$

for any $G \in(L, \bar{G})$. Since $-(1-\phi)(1-W(L)) Z(L)<0$ when $\phi<1$, then, for this case, the government's best response to a rebel attack is always to counterattack if $Z(\bar{G}-L)-(1-\phi)(1-$ $W(\bar{G})) Z(\bar{G})<0$, or, equivalently, if

$$
Z(\bar{G}-L)-(1-\phi)(1-W(\bar{G}))<0
$$

where I have used the fact that $Z(\bar{G})=1$. To identify the conditions under which (11) holds, define

$$
\bar{\phi} \equiv 1-\frac{Z(\bar{G}-L)}{(1-W(\bar{G}))}
$$

and note that under Assumption 3, $\bar{\phi}>0$. From (12), note that when $\phi<\bar{\phi}$, (11) holds. This means that when $\phi<\bar{\phi}$, the government's best response to a rebel attack is to also attack, regardless of the value of $G$. And since the rebel's best response to a government attack is clearly to attack, then whenever $\phi \leq \bar{\phi}$ and $\phi<1,(a, a)$ there is a Nash equilibrium for all $G \in(L, \bar{G})$. This proves Proposition 1.(ii).

From (12), note that $\bar{\phi}<1$, so there are values of $\phi$ such that $1>\phi>\bar{\phi}$. For these values, note that (11) does not hold. Combining this observation with the fact that $\frac{d D}{d G}>0$ for all $G \in(L, \bar{G})$ (and given any $\phi \in[0,1]$ ), we obtain that whenever $1>\phi>\bar{\phi}$, there exists $\hat{G}(\phi) \in(L, \bar{G})$, defined implicitly by

$$
Z(\hat{G}-L)=(1-\phi)(1-W(\hat{G})) Z(\hat{G})
$$

such that $(a, a)$ constitutes a Nash equilibrium if and only if $G \leq \hat{G}(\phi)$. To see that $\hat{G}^{\prime}(\phi)<0$, differentiate implicitly (13) with respect to $\phi$ to get $\hat{G}^{\prime}\left(\left.\frac{d D}{d G}\right|_{G=\hat{G}}\right)+(1-W(\hat{G})) Z(\hat{G})=0$; then note that the fact that for any $\phi \in[0,1], \frac{d D}{d G}>0$ for $G \in(L, \bar{G})$, and that $(1-W(\hat{G})) Z(\hat{G})>0$, imply that $\hat{G}^{\prime}<0$. This proves Proposition 1.(iii).

Finally, recall from the analysis above that the best response of both the rebels and government is to seek peace when their opponent also seeks peace. This implies that neither $(a, p)$ nor $(p, a)$ can constitute a Nash equilibrium (i.e., Proposition 1.(v)). This, combined with the fact that when $\phi=1, D=Z(G-L)>0$ for all $G \in(L, \bar{G})$ proves Proposition 1.(iv). 


\section{References}

Ali, Ali Abdel, Ibrahim A. Elbadawi, and Atta El-Batahani, "Sudan's Civil War. Why Has It Prevailed for So Long?," in Paul Collier and Nicholas Sambanis, eds., Understanding Civil War. Evidence and Analysis. Volume 1: Africa, World Bank, 2005, pp. 193-219.

Amegashie, J. Atsu and Edward Kutsoati, "(Non)intervention in intra-state conflicts," European Journal of Political Economy, September 2007, 23 (3), 754-767.

Avila, Ariel Fernando, "Del Caguán a la Habana," Informe, Corporacion Nuevo Arco iris 2013. [Online; accessed 28 April 2014].

Baik, Kyung Hwan and Sanghack Lee, "Two-Stage Rent-Seeking Contests with Carryovers," Public Choice, 2000, 103 (3/4), 285-296.

_, In-Gyu Kim, and Sunghyun Na, "Bidding for a group-specific public-good prize," Journal of Public Economics, 2001, 82 (3), 415 - 429.

Bakshi, Dripto and Indraneel Dasgupta, "Identity Conflict with Cross-Border Spillovers," Defence and Peace Economics, 2019, 0 (0), 1-24.

Balch-Lindsay, Dylan, Andrew J. Enterline, and Kyle A. Joyce, "Third-Party Intervention and the Civil War Process," Journal of Peace Research, 2008, 45 (3), 345-363.

Barbieri, Stefano, David A. Malueg, and Iryna Topolyan, "The best-shot all-pay (group) auction with complete information," Economic Theory, 2014, 57 (3), 603-640.

Blattman, Christopher and Edward Miguel, "Civil War," Journal of Economic Literature, March 2010, 48 (1), 3-57.

Bouckaert, Peter and Nadim Houry, Why They Died: Civilian Casualties in Lebanon During the 2006 War, Human Rights Watch, 2007.

Caracol Noticias, "Alias 'Timochenko' era el embajador de las Farc en Venezuela, según computadores de 'Raúl Reyes'," March 2 2010. Online; consulted 1 April 2014.

_ , "Lea aquí el discurso completo del expresidente Alvaro Uribe," October 282012. Online; consulted 1 April 2014.

Carlos Lozano's website, "Comandante Timoleón Jiménez: "Hemos estado dispuestos a la búsqueda de la Paz"," september 19 2012. Online; consulted 1 April 2014.

Carment, David and Dane Rowlands, "Three's Company: Evaluating Third-Party Intervention in Intrastate Conflict," Journal of Conflict Resolution, 1998, 42 (5), 572-599.

_ and _ , "Force and Bias: Towards a Predictive Model of Effective Third-Party Intervention," Defence and Peace Economics, 2006, 17 (5), 435-456.

Chernick, Marc, "The FARC at the Negotiating Table," in Virginia Marie Bouvier, ed., Colombia: Building Peace in a Time of War, United States Institute of Peace Press, 2009.

Choi, Jay Pil, Subhasish M. Chowdhury, and Jaesoo Kim, "Group Contests with Internal Conflict and Power Asymmetry," The Scandinavian Journal of Economics, 2016, 118 (4), 816-840. 
Chowdhury, Subhasish M. and Iryna Topolyan, "The Attack-And-Defense Group Contests: Best Shot Versus Weakest Link," Economic Inquiry, January 2016, 54 (1), 548-557.

_ and _, "Best-shot versus weakest-link in political lobbying: an application of group all-pay auction," Social Choice and Welfare, December 2016, 47 (4), 959-971.

_ , Dongryul Lee, and Iryna Topolyan, "The Max-Min Group Contest: Weakest-link (Group) All-Pay Auction," Southern Economic Journal, 2016, 83 (1), 105-125.

Crawford, Timothy W., "Pivotal Deterrence and the Kosovo War: Why the Holbrooke Agreement Failed," Political Science Quarterly, 2001, 116 (4), pp. 499-523.

_, Pivotal Deterrence: Third-party Statecraft and the Pursuit of Peace, Cornell University Press, 2003.

Cunningham, David E., Kristian Skrede Gleditsch, and Idean Salehyan, "It Takes Two: A Dyadic Analysis of Civil War Duration and Outcome," Journal of Conflict Resolution, 2009, 53 (4), 570-597.

_ , Kristian Skrede Gleditsch, and Idean Salehyan, "Explaining External Support for Insurgent Groups," International Organization, 9 2011, 65, 709-744.

Davila, Vicky, Enemigos: Santos y Uribe Por qué se odian?, Editorial CAMM, 2014.

El Tiempo, "Búsqueda de 'Timochenko', 'papa caliente' para Colombia y Venezuela," November 19 2011. Online; consulted 1 May 2014.

_ , "Timochenko', otro radical en la jefatura de las Farc," November 15 2011. Online; consulted 1 May 2014.

FARC-EP, "The Conversation Table, a triumph of the national clamor for peace and the political solution," August 2013. Online; consulted 1 April 2014.

_ , "El 'tope' de las FARC-EP," February 12 2013. Online; consulted 1 May 2014.

Fearon, James D., "Commitment Problems and the Spread of Ethnic Conflict," 1998, pp. 107-126.

Financial Times, "Chavez ups rhetoric in spat with Colombia," August 2009. Online; consulted 24 May 2020.

Gleditsch, Kristian Skrede, "Transnational Dimensions of Civil War," Journal of Peace Research, 2007, 44 (3), 293-309.

- and Kyle Beardsley, "Nosy Neighbors: Third-Party Actors in Central American Conflicts," The Journal of Conflict Resolution, 2004, 48 (3), pp. 379-402.

GMH, Grupo de Memoria Histórica: Basta ya! Colombia: memorias de guerra y dignidad. Informe General, Imprenta Nacional, 2013.

Gunter, Michael M., The Kurds Ascending: The Evolving Solution to the Kurdish Problem in Iraq and Turkey, Palgrave Macmillan, 2008. 
Hausken, Kjell, "Production and Conflict Models Versus Rent-Seeking Models," Public Choice, 2005, 123 (1), 59-93.

Hegre, Hvard and Nicholas Sambanis, "Sensitivity Analysis of Empirical Results on Civil War Onset," Journal of Conflict Resolution, 2006, 50 (4), 508-535.

IISS, "The Farc Files: Venezuela, Ecuador and the Secret Archive of 'Raúl Reyes'," IISS Strategic Dossier, International Institute for Strategic Studies (IISS) 2011. [Online; accessed 28 April 2014].

Jackson, Matthew O. and Massimo Morelli, "The Reasons for Wars - an Updated Survey," in Chris Coyne and Rachel Mathers, eds., Handbook on the Political Economy of War, Elgar Publishing, 2011.

Kline, Harvey F., Chronicle of a Failure Foretold: The Peace Process of Colombian President Andrés Pastrana, The University of Alabama Press, 2007.

Kuperman, Alan J., "The Moral Hazard of Humanitarian Intervention: Lessons from the Balkans," International Studies Quarterly, 2008, 52 (1), 49-80.

Kydd, Andrew H. and Scott Straus, "The Road to Hell? Third-Party Intervention to Prevent Atrocities," American Journal of Political Science, 2013, 57 (3), 673-684.

Mason, T. David, Joseph P Weingarten, and Patrick J. Fett, "Win, Lose, or Draw: Predicting the Outcome of Civil Wars," Political Research Quarterly, 1999, 52 (2), 239-268.

Maynard, Jonathan Leader, "Ideology and armed conflict," Journal of Peace Research, 2019, 56 (5), 635-649.

Ministerio de Defensa, "Logros de la Politica de Consolidación de la Seguridad Democrática," July 2009.

Morelli, Massimo and Costantino Pischedda, "Oil, Federalism, and Third-Party Intervention: An Assessment of Conflict Risk in Iraqi Kurdistan," Technical Report 2013.

Münster, Johannes, "Simultaneous inter- and intra-group conflicts," Economic Theory, 2007, 32 (2), 333-352.

Münster, Johannes and Klaas Staal, "War with Outsiders Makes Peace Inside," Conflict Management and Peace Science, 2011, 28 (2), 91-110.

Nasi, Carlo, "Colombia's Peace Processes, 1982-2002. Conditions, Strategies, and Outcomes," in Virginia Marie Bouvier, ed., Colombia: Building Peace in a Time of War, United States Institute of Peace Press, 2009.

OAS, "OAS Calls for Dialogue and Cooperation in Bilateral Relations between Colombia and Venezuela," July 22 2010. Online; consulted 1 May 2014.

Owen, John M., The Clash of Ideas in World Politics: Transnational Networks, States, and Regime Change, 1510-2010, Princeton University Press, 2010.

Presidencia, "Presidencia de Colombia: Secretaría de Prensa," July 162010. 
_, "Presidencia de Colombia: Alocución del Presidente de la República, Juan Manuel Santos sobre el 'Acuerdo General para la Terminación del Conflicto'," September 2012.

_ , "Presidencia de Colombia: Ni un solo dia ni un solo minuto vamos a bajar la guardia ante los actores violentos," October 2012.

Revista Semana, "El juego de Chávez," January 19 2008. Online; consulted 24 May 2020.

_ , "Por qué Santos," June 12 2010. Online; consulted 1 May 2014.

_ , "Qué se sabe del proceso de paz," September 3 2012. Online; consulted 1 May 2014.

Rico, Daniel, "En qué estado militar están las FARC?," April 2013. Online; posted 21 April 2013, consulted 1 April 2014.

Sanchez, Gonzalo, "Problems of Violence, Prospects for Peace," in Charles W. Bergquist, Gonzalo Sanchez, and Ricardo Penaranda, eds., Violence in Colombia, 1990-2000: Waging War and Negotiating Peace, Wilmington, Del.: SR Books, 2001.

Serbin, Andres and Andrei Serbin, "The Foreign Policy of the Bolivarian Republic of Venezuela: The Role and Legacy of Hugo Chvez," Latin American Policy, 2017, 8 (2), 232-248.

South, Ashley, Ethnic Politics in Burma: States of Conflict, Routledge, 2008.

_ , "The Politics of Protection in Burma: beyond the humanitarian mainstream," Critical Asian Studies, 2012, 44 (2), 175-204.

Stein, William E. and Amnon Rapoport, "Asymmetric Two-Stage Group Rent-Seeking: Comparison of Two Contest Structures," Public Choice, 2004, 118 (1), 151-167.

The New York Times, "Crisis at Colombia Border Spills Into Diplomatic Realm," March 42008. Online; consulted 1 May 2014.

_ , "Colombia Signs Peace Agreement With FARC After 5 Decades of War," September 262016. Online; consulted 1 Jun 2018.

_ , "Colombia's President, Juan Manuel Santos, Is Awarded Nobel Peace Prize," October 72016. Online; consulted 1 Jun 2018.

Werner, Suzanne, "Deterring Intervention: The Stakes of War and Third-Party Involvement," American Journal of Political Science, 2000, 44 (4), pp. 720-732.

Zartman, I William, "Ripeness: The Hurting Stalemate and Beyond," in Paul Stern and Daniel Druckman, eds., International Conflict Resolution After the Cold War, National Academy Press, 2000 . 